\title{
Egg and larval amino acid composition as indicators of niche resource partitioning in pelagic fish species
}

\author{
Isabel Riveiro ${ }^{1, *}$, Cástor Guisande ${ }^{1}$, Concha Franco ${ }^{2}$, Ana Lago de Lanzós², \\ Isabel Maneiro', Alba Ruth Vergara ${ }^{1}$
}

${ }^{1}$ Facultad de Ciencias del Mar, Universidad de Vigo, 36200 Vigo, Spain

${ }^{2}$ Instituto Español de Oceanografía, Av. de Brasil 31, 28020 Madrid, Spain

\begin{abstract}
We analysed the amino acid composition (AA) of eggs and larvae of the pelagic fish species Sardina pilchardus (sardine), Scomber scombrus (mackerel), Trachurus trachurus (horse mackerel) and Micromesistius poutasou (blue whiting) collected along the west Atlantic coast of Spain and from the Cantabrian Sea during March to April 2000. A discriminant analysis showed that it was possible to distinguish each fish species according to the egg and larval AA. Moreover, egg and larval AA varied among different areas within each fish species. From the data of larval abundance obtained from 5 cruises carried out along the northern Spanish coast from 1995 to 2000 (Mph-1995, Sefos-1995, Careva-1998, Jureva-1998 and Seamar-2000), the temporal and spatial overlap among fish species was estimated. There was a significant relationship between larval AA similarity and larval spatial-temporal overlap among fish species, which means that those larval species that had greater spatial and temporal overlap, had a similar larval AA. On this basis, the differences in egg and larval AA within each fish species among different areas seem to be due to differences in habitat conditions; mainly temperature, salinity, and food quality and quantity. We concluded that egg and larval AA could be used as indicators of niche resource partitioning (food resources and spatial allocation) among pelagic fish species.
\end{abstract}

KEY WORDS: Fish $\cdot$ Egg $\cdot$ Larvae $\cdot$ Amino acid $\cdot$ Niche $\cdot$ Population Resale or republication not permitted without written consent of the publisher

\section{INTRODUCTION}

Egg biochemical composition in pelagic fishes is species specific (Guisande et al. 1998), although seasonal and spatial variations within each species have been observed (Guisande et al. 1998, Riveiro et al. 2000). These seasonal and spatial variations in the egg biochemical composition are mainly due to adult diet and/or parental strategies. Both lipid and amino acid composition of the eggs are affected by changes in adult dietary composition (Silversand et al. 1996, Pereira et al. 1998). Parental strategies could also lead to changes in egg biochemical composition as a mechanism to maximise egg and larval survival under the prevailing habitat conditions: prey availability, temperature, salinity, etc (Brown \& Taylor 1992, Nissling \& Vallin 1996, Guisande et al. 1998, Riveiro et al. 2000).
Larval biochemical composition in pelagic fishes may also be affected by the parental strategies mentioned above, through changes in egg quality (Baynes \& Howell 1996). Additionally, this can also vary according to food quantity and quality during larval fish development (Buckley \& Lough 1987). During larval development, tissues are synthesised at different times and at different rates (Osse et al. 1997), potentially affecting biochemical composition.

Egg and larval biochemical composition could be good indicators of the diet of adults and their offspring and/or adult and larval habitat allocation, and hence, both egg and larval biochemical composition could be used to trace the niche of each fish population. However, the problem is to identify the biochemical components liable to vary according to the prevailing environmental conditions. Fatty acid profiles have been 
successfully used to discriminate among: (1) fish eggs of different age and species (Ulvund \& Grahl-Nielsen 1988); (2) fish stocks (Grahl-Nielsen \& Mjvaatten 1992); and (3) larvae with different diets (Navarro et al. 1995).

Recently, it has been shown in some zooplankton species that amino acid composition (AA) is species specific, and furthermore, AA is a good indicator of food resources (Guisande et al. 1999, 2000, 2002). Some authors have pointed out that differences in the amino acid profile in eggs or larvae of fishes may have important implications in terms of amino acid requirements within the diet (Ketola 1982, Conceição et al. 1998). If the AA of fish eggs and/or larvae is also species specific, and moreover, varies according to the habitat characteristics/feeding needs, amino acids may also be a useful tool in the ecological study of pelagic fish populations.

Sardina pilchardus (sardine), Scomber scombrus (mackerel), Trachurus trachurus (horse mackerel) and Micromesistius poutasou (blue whiting) are some of the most abundant pelagic fish species to be found along the coasts of northern Spain and the Atlantic as well as on those of the Cantabrian Sea. Studies on the diet composition of these fish species have demonstrated a preference for copepod eggs and larvae during the fish larval stage (Martin-Jézéquel et al. 1989, Conway et al. 1994, 1999, Hillgruber \& Kloppmann 1999), with the exception of sardine larvae, which also feed actively on phytoplankton (Rasoanarivo et al. 1991). Adults of sardine feed on algae and crustaceans, mackerel adults have a diet based on fish, crustaceans and gastropods, horse mackerel feed mainly on crustaceans, fish and molluscs and blue whiting adults have as prey preference fish, crustaceans and cephalopods (Stergiou \& Karpouzi 2002).

The aim of this study was to determine whether egg and larval AA is species specific and whether it changes according to habitat conditions.

\section{MATERIALS AND METHODS}

Ichthyoplankton collection. Temporal and spatial overlap among fish species were estimated from larval abundance data obtained in 5 cruises carried out along the North and Northwest coast of the Iberian Peninsula. Egg and larvae were collected using oblique bongo nets: MPH95 (20 cm, $200 \mu \mathrm{m}$ mesh size), SEFOS95 $(20 \mathrm{~cm}, 200 \mu \mathrm{m})$, CAREVA98 $(40 \mathrm{~cm}$, $250 \mu \mathrm{m})$, JUREVA98 $(40 \mathrm{~cm}, 250 \mu \mathrm{m})$ and SEAMAR00 $(50 \mathrm{~cm}, 250 \mu \mathrm{m})$ on the RV 'Cornide de Saavedra'.

Eggs and larvae for the amino acids analyses were collected in the Cantabrian Sea during the Seamar cruise during March to April 2000, and off the Atlantic coast of Galicia (northwest of Spain) in the RV 'Jose $\mathrm{M}^{\mathrm{a}}$ Navaz' at 3 separate stations: $42^{\circ} 8.5^{\prime} \mathrm{N}, 8^{\circ} 57.5^{\prime} \mathrm{W}$; $42^{\circ} 12.8^{\prime} \mathrm{N}, 8^{\circ} 51^{\prime} \mathrm{W} ;$ and $42^{\circ} 13.3^{\prime} \mathrm{N}, 8^{\circ} 47.7^{\prime} \mathrm{W}$ in March and April 2000. In these cruises, we only found Sardina pilchardus and Scomber scombrus eggs, whereas we collected larvae of the 4 species Sardina pilchardus, Scomber scombrus, Trachurus trachurus and Micromesistius poutasou. After staging and measuring, eggs (between 1 and 3 eggs of the same stage and similar size per vial) and larvae (1 larva per vial) were transferred to ultracentrifuge plastic vials with $300 \mu \mathrm{l}$ of bidistilled water and immediately frozen at $-30^{\circ} \mathrm{C}$. Samples were homogenised using a pipette tip adapted to fit the shape of the vial. The size of larvae ranged between 4.0 and $26.3 \mathrm{~mm}$ with a mean of $12.2 \mathrm{~mm}$ for sardine, 2.9 to $25.7 \mathrm{~mm}$ with a mean of $9.0 \mathrm{~mm}$ for mackerel, 3.8 to 8.7 with a mean of $5.3 \mathrm{~mm}$ for horse mackerel, and 5.5 and 20.9 with a mean of $9.1 \mathrm{~mm}$ for blue whiting.

Seston collection. The protein, carbohydrate and lipid content of the seston fraction between 20 and $1000 \mu \mathrm{m}$, as described by Riveiro et al. (2000), was used as an indicator of the quality of food potentially available to the larvae. In the stations in which we collected eggs or larvae for amino acid analysis, $20 \mathrm{~m}$ vertical net hauls (using a $20 \mu \mathrm{m}$ mesh net equipped with a flow meter) were towed at each station.

Biochemical analysis. The 20 to $1000 \mu \mathrm{m}$ fraction was re-suspended in $500 \mathrm{ml}$ of filtered seawater and sub-samples were taken for protein $(15 \mathrm{ml})$, carbohydrate $(15 \mathrm{ml})$ and lipid (50 ml) analyses.

Egg and larval amino acid composition were analysed by HPLC using a Waters Alliance System, a Waters 474 scanning fluorescence detector and a Waters $15 \times 3.9$ Nova-Pack C18 column following the method described by Van Wandelen \& Cohen (1997). Amino acid standard H NCI0180 Pierce was used for the identification and quantification of amino acids. For amino acid analysis, $80 \mu \mathrm{l}$ of each egg or $10 \mu \mathrm{l}$ of each larval homogenate were used.

The method described by Lowry et al. (1951) and modified by Maxwell et al. (1978) was used to analyse the protein seston content. Carbohydrate seston content was measured by the phenol-sulphuric acid method (Dubois et al. 1956) and the lipid seston content was determined using the sulfophosphovanillin method (Zöllner \& Kirsch 1962). Protein, carbohydrate and lipid analyses of eggs and larvae are further described in Guisande et al. (1998).

Discrimination among species and areas. As some previous studies observed differences between the west Cantabrian Sea, east Cantabrian Sea and the Atlantic coast in the age structure of the population (Porteiro et al. 1986), proportion of males and females (Abaunza et al. 1995) and larval growth rate (Alvárez \& 
Alemany 1992), we considered 3 different areas: (1) the Atlantic coast; (2) the west Cantabrian Sea (from the Atlantic coast to $5^{\circ} \mathrm{W}$ ); and (3) the east Cantabrian Sea (from $5^{\circ} \mathrm{W}$ to the French coast).

To determine whether it is possible to discriminate among fish species and areas according to the AA of the eggs and larvae, a discriminant analysis (a multivariate variable statistical method) was applied to the AA data. Discriminant analysis is a pattern-recognition method that helps to separate 2 or more groups from data provided for several variables. Discriminant analysis has been successfully used in trophic relationship studies of fish larvae, for which it facilitated a larval classification according to their diet based on fatty acid composition (Navarro et al. 1995). In copepods, discriminant analysis of amino acid composition has also proven to be a useful tool in discriminating between different species (Guisande et al. 2002).

Temporal and spatial overlap among larval species. A factorial analysis using the covariance matrix was performed on the relative abundance data of the 5 cruises to obtain a graphic representation of the spatial overlap or degree of co-occurrence among species.

Temporal and spatial overlap was estimated by the simplified Morisita index $\left(C_{H}\right)$ proposed by Horn (1966):

$$
C_{H}=\frac{2 \sum_{i=1}^{n} p_{i j} p_{i k}}{\sum_{i=1}^{n} p_{i j}^{2}+\sum_{i=1}^{n} p_{i k}^{2}}
$$

where $n$ is the number of samples, $p_{i j}$ and $p_{i k}$ are the ratios: abundance of the species $j$ and $k$ in the sample $i$ total abundance in all samples of the species $j$ and $k$, respectively. The data were pooled from all stations and surveys to estimate the values of $p_{i j}$ and $p_{i k}$.

Similarity index. Average Euclidean distance $\left(D_{j k}\right)$ was used to estimate similarity in larval AA among fish species.

$$
D_{i j}=\sqrt{\frac{\sum_{i=1}^{n}\left(X_{i j}-X_{i k}\right)^{2}}{n}}
$$

where $X_{i j}$ and $X_{i k}$ are polar co-ordinates in Axes I and II, respectively, obtained from the discriminant analysis performed on the data of larval AA, for the species $j$ and $k$. A higher similarity is obtained when the Euclidean distance is smaller.

All multivariate analyses were performed with SPSS 11.0 .

\section{RESULTS}

From the data collected during the 5 cruises, we observed that Sardina pilchardus, Scomber scombrus and Trachurus trachurus were distributed throughout the Cantabrian Sea, whereas larvae of Micromesistius poutassou were only found in the west area of the Cantabrian Sea (Fig. 1). High concentrations of $S$. pilchardus were also observed along the Atlantic coast, in an area close to Porto (Portugal). Table 1 shows the number of stations sampled for each cruise, the number of stations in which we found larvae and the mean larval abundance of each species considering all the stations.

For all species and areas, the major amino acids in the eggs were glu, arg, ala, val, lys, ile and leu; whereas in larvae, they were glu, gly, arg, ala, val, lys and leu (Table 2). Martin-Jézéquel et al. (1989) observed that the major amino acids in the midguts of post-larvae Scomber scombrus and Trachurus trachurus were the same as the ones observed in this study, with the exception of glu, despite the fact that they analysed free amino acids, whereas we analysed total amino acids.

A discriminant analysis performed on the data of the AA of Sardina pilchardus and Scomber scombrus eggs showed that it is possible to identify each fish species and the spatial allocation of the eggs according to their AA (Fig. 2a). The first component of the discriminant analysis explained $83.5 \%$ of the variance and discriminates among different species. The second component explained only $7.6 \%$ of the variance and discriminates among different areas, particularly between the East and the West of the Cantabrian Sea. Further, there

Table 1. Number of stations sampled, number of stations where each species was present $(\mathrm{P})$ and the mean $\pm \mathrm{SD}$ abundance of the

\begin{tabular}{|c|c|c|c|c|c|c|c|c|c|c|}
\hline \multirow{2}{*}{ No. of stations sampled: } & \multicolumn{2}{|c|}{$\begin{array}{c}\text { CAREVA98 } \\
93\end{array}$} & \multicolumn{2}{|c|}{$\begin{array}{c}\text { JUREVA98 } \\
52\end{array}$} & \multicolumn{2}{|r|}{$\begin{array}{c}\text { MPH95 } \\
112\end{array}$} & \multicolumn{2}{|c|}{$\begin{array}{c}\text { SEFOS95 } \\
121\end{array}$} & \multicolumn{2}{|c|}{$\begin{array}{c}\text { SEAMAR0400 } \\
103\end{array}$} \\
\hline & $\mathrm{P}$ & $\mathrm{A}$ & $\mathrm{P}$ & $\mathrm{A}$ & $\mathrm{P}$ & $\mathrm{A}$ & $\mathrm{P}$ & $\mathrm{A}$ & $\mathrm{P}$ & $\mathrm{A}$ \\
\hline Sardina pilchardus & 51 & $83.68 \pm 114.52$ & 27 & $58.88 \pm 121.85$ & 65 & $57.41 \pm 109.40$ & 54 & $82.24 \pm 107.73$ & 57 & $144.63 \pm 266.06$ \\
\hline Scomber scombrus & 19 & $6.82 \pm 8.23$ & 22 & $55.31 \pm 63.35$ & 47 & $44.97 \pm 128.69$ & 18 & $10.18 \pm 8.14$ & 57 & $28.06 \pm 82.79$ \\
\hline Trachurus trachurus & 28 & $5.66 \pm 6.54$ & 26 & $13.19 \pm 18.95$ & 46 & $13.8 \pm 12.10$ & 60 & $51.44 \pm 77.57$ & 44 & $26.55 \pm 51.63$ \\
\hline Micromesistius poutassou & 4 & $2.07 \pm 1.21$ & 1 & $0.94 \pm 0.00$ & 8 & $14.70 \pm 15.80$ & 0 & & 24 & $11.06 \pm 24.50$ \\
\hline
\end{tabular}
species $\left(\mathrm{A}\right.$, larvae $\mathrm{m}^{-2}$ ) obtained for all cruises 

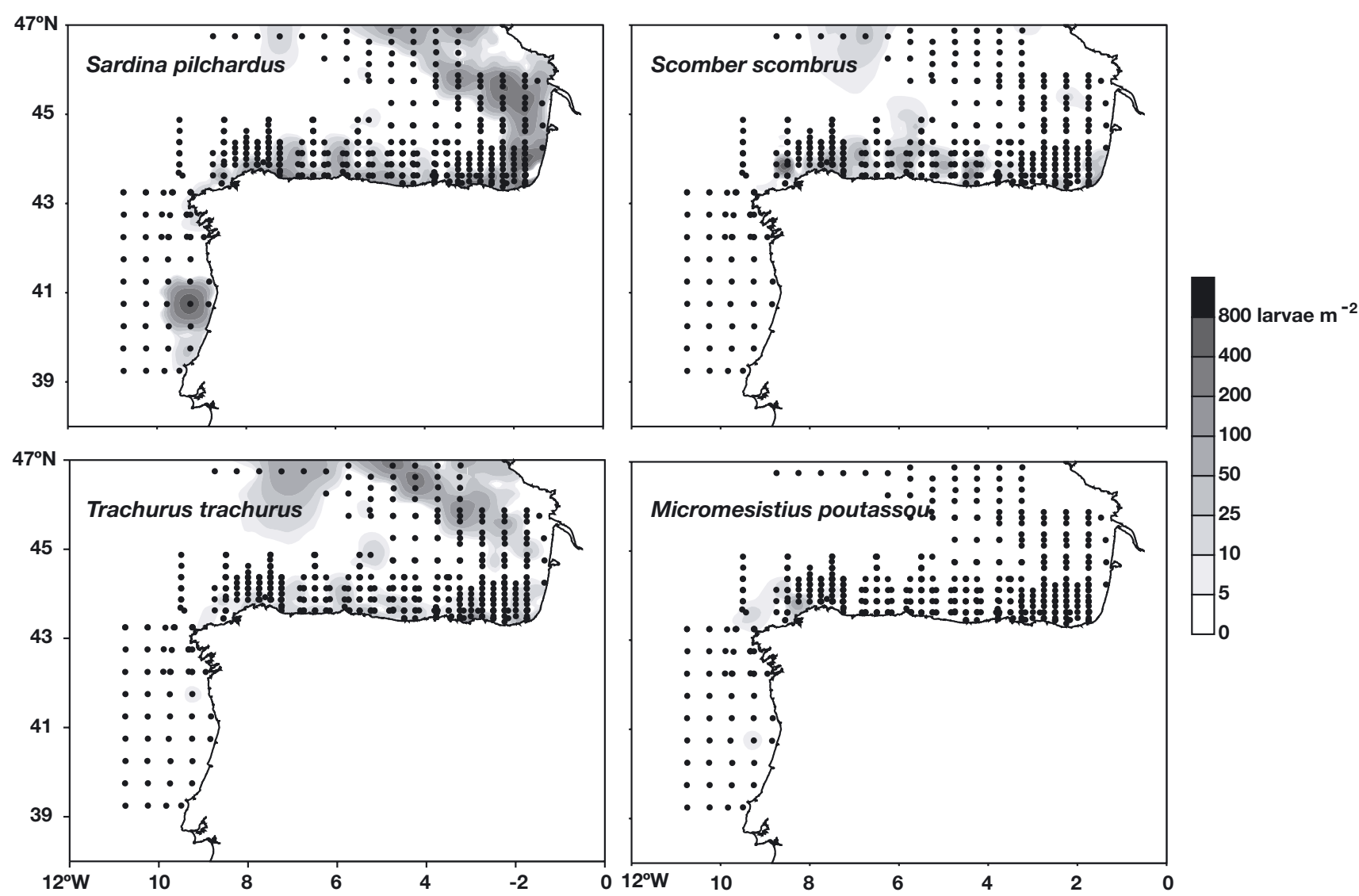

Fig. 1. Spatial distribution of Sardina pilchardus, Scomber scombrus, Trachurus trachurus and Micromesistius poutasou larvae (in larvae $\mathrm{m}^{-2}$ ) using the data obtained from the 5 cruises, with positions of the sampling stations $(\bullet)$ indicated. This contour map was performed with the program 'Surfer' and the gridding method was the inverse distance to a power

Table 2. Amino acid composition as mean \pm SD weight percentage of total amino acids yields of Sardina pilchardus (Sp), Scomber scombrus $(\mathrm{Ss})$, Trachurus trachurus ( $\mathrm{Tt}$ ) and Micromesistius poutasou (Mp) eggs and larvae captured along the Atlantic coast (At) and in the West (W) and the East (E) of the Cantabrian Sea. $\mathrm{n}=$ number of samples analysed (with 2 to 3 eggs or 1 larva). Amino acid abbreviations are: Asp: aspartic acid, ser: serine, glu: glutamic acid, gly: glycine, his: histidine, arg: arginine, thr: threonine, ala: alanine, pro: proline, tyr: tyrosine, val: valine, lys: lysine, ile: isoleucine, leu: leucine, phe: phenylalanine

\begin{tabular}{|c|c|c|c|c|c|c|c|c|c|c|c|c|c|}
\hline & \multirow[b]{2}{*}{ Sp At } & \multirow[b]{2}{*}{$S p \mathrm{~W}$} & \multirow{2}{*}{$\begin{array}{c}\text { Eggs } \\
\text { Sp E }\end{array}$} & \multirow[b]{2}{*}{ Ss W } & \multirow[b]{2}{*}{ Ss E } & \multirow[b]{2}{*}{$S p$ At } & \multirow[b]{2}{*}{$S p \mathrm{~W}$} & \multirow[b]{2}{*}{$S p \mathrm{E}$} & \multirow{2}{*}{$S_{S s} \mathrm{~W}$} & \multirow[b]{2}{*}{ Ss E } & \multirow[b]{2}{*}{$T t \mathrm{~W}$} & \multirow[b]{2}{*}{$T t \mathrm{E}$} & \multirow[b]{2}{*}{$M p \mathrm{~W}$} \\
\hline & & & & & & & & & & & & & \\
\hline $\mathrm{n}$ & 30 & 8 & 8 & 22 & 31 & 4 & 76 & 59 & 87 & 9 & 7 & 3 & 34 \\
\hline Asp & $6.7 \pm 0.5$ & $6.7 \pm 0.5$ & $6.7 \pm 1.0$ & $6.7 \pm 0.9$ & $6.2 \pm 0.4$ & $10.1 \pm 0.3$ & $9.4 \pm 0.6$ & $9.3 \pm 0.6$ & $9.2 \pm 0.5$ & $9.2 \pm 0.4$ & $9.2 \pm 1.1$ & $9.8 \pm 0.2$ & $9.2 \pm 0.3$ \\
\hline Ser & $6.9 \pm 0.8$ & $7.2 \pm 1.6$ & $7.4 \pm 0.9$ & $7.3 \pm 1.0$ & $6.9 \pm 0.6$ & $4.6 \pm 0.9$ & $5.2 \pm 0.5$ & $5.5 \pm 1.2$ & $5.7 \pm 0.4$ & $5.2 \pm 0.3$ & $5.4 \pm 0.3$ & $4.9 \pm 0.5$ & $5.6 \pm 0.5$ \\
\hline Glu & $11.8 \pm 0.6$ & $11.6 \pm 0.3$ & $11.7 \pm 1.1$ & $12.7 \pm 0.9$ & $12.0 \pm 0.9$ & $16.2 \pm 0.4$ & $14.7 \pm 0.8$ & $14.9 \pm 0.8$ & $13.7 \pm 0.6$ & $14.0 \pm 0.6$ & $14.2 \pm 1.3$ & $14.8 \pm 0.3$ & $13.6 \pm 0.4$ \\
\hline Gly & $4.4 \pm 1.0$ & $4.3 \pm 1.2$ & $4.9 \pm 0.9$ & $4.8 \pm 1.3$ & $4.3 \pm 1.0$ & $6.1 \pm 1.6$ & $6.1 \pm 0.6$ & $7.0 \pm 1.2$ & $6.7 \pm 0.5$ & $6.7 \pm 0.5$ & $6.6 \pm 0.4$ & $7.2 \pm 0.4$ & $6.8 \pm 0.6$ \\
\hline His & $2.8 \pm 0.2$ & $2.7 \pm 0.2$ & $2.9 \pm 0.4$ & $3.2 \pm 0.2$ & $3.5 \pm 0.2$ & $2.5 \pm 0.1$ & $3.0 \pm 0.4$ & $2.9 \pm 0.3$ & $3.5 \pm 0.4$ & $3.3 \pm 0.1$ & $2.9 \pm 0.2$ & $2.9 \pm 0.0$ & $3.1 \pm 0.5$ \\
\hline Arg & $8.5 \pm 0.5$ & $8.9 \pm 0.6$ & $8.7 \pm 0.8$ & $9.2 \pm 0.7$ & $8.8 \pm 0.6$ & $9.0 \pm 0.6$ & $9.2 \pm 0.9$ & $8.6 \pm 1.0$ & $9.4 \pm 1.0$ & $8.4 \pm 0.7$ & $9.0 \pm 0.7$ & $8.6 \pm 0.2$ & $10.4 \pm 1.1$ \\
\hline Thr & $5.8 \pm 0.3$ & $6.2 \pm 0.5$ & $5.7 \pm 0.6$ & $5.1 \pm 0.4$ & $4.6 \pm 0.3$ & $4.7 \pm 0.3$ & $4.6 \pm 0.5$ & $4.5 \pm 0.5$ & $5.0 \pm 0.3$ & $4.9 \pm 0.3$ & $4.7 \pm 0.2$ & $4.7 \pm 0.1$ & $4.9 \pm 0.3$ \\
\hline Ala & $9.0 \pm 0.7$ & $8.8 \pm 1.0$ & $6.3 \pm 1.0$ & $9.6 \pm 1.3$ & $9.9 \pm 1.3$ & $6.7 \pm 0.5$ & $5.7 \pm 0.6$ & $6.1 \pm 0.9$ & $5.5 \pm 0.7$ & $6.5 \pm 0.4$ & $6.2 \pm 0.6$ & $7.3 \pm 1.3$ & $5.6 \pm 0.7$ \\
\hline Pro & $3.4 \pm 1.3$ & $5.8 \pm 0.8$ & $6.0 \pm 0.9$ & $4.4 \pm 0.4$ & $4.6 \pm 0.4$ & $5.2 \pm 0.3$ & $5.4 \pm 0.5$ & $5.6 \pm 1.1$ & $5.4 \pm 0.4$ & $5.5 \pm 0.3$ & $5.3 \pm 0.5$ & $4.8 \pm 0.1$ & $5.2 \pm 0.5$ \\
\hline Tyr & $2.3 \pm 0.7$ & $0.8 \pm 0.5$ & $1.8 \pm 0.5$ & $1.1 \pm 0.5$ & $2.1 \pm$ & \pm 0.7 & 3.6 & $1.9 \pm 1.1$ & $4.1 \pm 0.9$ & 1.9 & $3.1=$ & 0.9 & $4.5 \pm 0.9$ \\
\hline Val & $3.0 \pm 0.5$ & $9 \pm 0.4$ & $.2 \pm 0.7$ & $6.6 \pm 0.5$ & $7.2 \pm 0.3$ & $5.7 \pm 0.6$ & $5.8 \pm 0.7$ & $6.0 \pm 0.5$ & $5.7 \pm 0.6$ & $6.3 \pm 0.2$ & $5.8 \pm 0.2$ & $6.1 \pm 0.1$ & $5.6 \pm 0.6$ \\
\hline Lys & $8.1 \pm 0.5$ & $7.3 \pm 0.6$ & $8.3 \pm 1.2$ & $8.3 \pm 0.9$ & $8.6 \pm 0.5$ & $9.5 \pm 0.9$ & $9.1 \pm 0.7$ & $9.4 \pm 1.4$ & $8.4 \pm 0.6$ & $8.9 \pm 0.7$ & $9.1 \pm 0.4$ & $9.4 \pm 0.5$ & $7.8 \pm 0.5$ \\
\hline Ile & $7.9 \pm 0.5$ & $8.0 \pm 0.7$ & $7.2 \pm 0.4$ & $7.7 \pm 0.5$ & $7.2 \pm 0.6$ & $5.8 \pm 0.3$ & $5.1 \pm 0.4$ & $5.3 \pm 0.5$ & $5.1 \pm 0.4$ & $5.7 \pm 0.6$ & $5.2 \pm 0.4$ & $5.4 \pm 0.1$ & $4.9 \pm 0.5$ \\
\hline Leu & $10.7 \pm 0.6$ & $10.0 \pm 1.0$ & $10.3 \pm 1.4$ & $9.3 \pm 0.5$ & $9.8 \pm 0.9$ & $8.3 \pm 0.4$ & $8.3 \pm 0.9$ & $8.4 \pm 0.7$ & $7.8 \pm 1.2$ & $8.6 \pm 0.5$ & $8.6 \pm 0.3$ & $8.6 \pm 0.1$ & $7.8 \pm 1.2$ \\
\hline Phe & $3.6 \pm 0.2$ & $3.9 \pm 0.1$ & $3.9 \pm 0.2$ & $4.1 \pm 0.3$ & $4.4 \pm 0.3$ & $4.2 \pm 0.1$ & $4.8 \pm 0.4$ & $4.5 \pm 0.4$ & $5.0 \pm 0.4$ & $4.9 \pm 0.3$ & $4.8 \pm 0.2$ & $4.6 \pm 0.1$ & $5.1 \pm 0.3$ \\
\hline
\end{tabular}


were no important differences in the AA of $S$. pilchardus eggs between the Atlantic coast and East Cantabrian Sea. The percentage of egg fish species correctly classified according to its AA represented the $94.9 \%$ of the cases (Table 3 ). The AA of eggs mainly differs among species in the proportion of his, thr, val and phe, and among areas in the proportion of thr and tyr (Table 4).

Larval amino acid composition was also significantly different between species and areas (Fig. 2b). However, for larval AA, a higher proportion of the variance is explained by differences between areas (first component with $43.8 \%$ of the variance) than by differences among species (second component with $33.1 \%$ of the variance). The percentage of larvae correctly classified according to its AA amounted to $81 \%$ of total cases (Table 3). The AA of larvae mainly differs among areas in proportion to glu, tyr, lys and phe, and among species in proportion to his, thr and glu (Table 4).

A plot of factorial analysis performed using the larval abundance data gives a graphical representation of the spatial and temporal co-occurrence among larval species in the East and West sides of the Cantabrian Sea (Fig. 3). The differences in temporal-spatial larval distribution among fish species on both East and West sides of the Cantabrian Sea show a similar pattern to the differences observed in larval AA in both areas (Fig. 2). Larval species that more spatially and temporally overlapped had a similar larval AA (Fig. 4). A discriminant analysis performed using the percentage of proteins, carbohydrates and lipids of the seston fraction between 20 and $1000 \mu \mathrm{m}$ showed clear differences in the quality of the food available to adults and/or larvae among areas (Fig. 5). The first component of the discriminant analysis explained $70.3 \%$ of the variance and the second component explained $29.7 \%$ of the variance. The percentage of seston areas correctly classified according to the biochemical composition represented $95.5 \%$ of all cases.
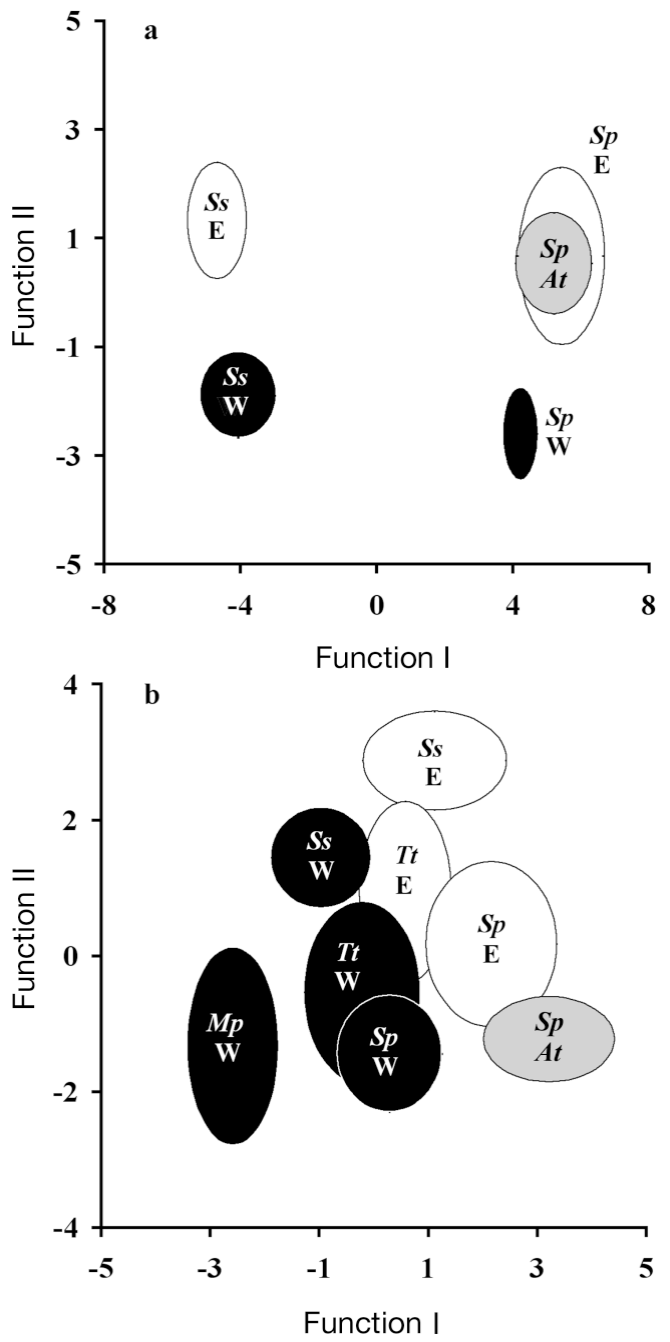

Fig. 2. Plots of the mean $\pm \mathrm{SD}$ of the scores for the first 2 discriminant scores for (a) the AA of the eggs and (b) the AA of the larvae. West Cantabrian Sea (W: black), east Cantabrian Sea (E: white) and Atlantic coast (At: shaded). Sardina pilchardus (Sp), Scomber scombrus (Ss), Trachurus trachurus (Tt) and Micromesistius poutasou (Mp)

Table 3. Results of a discriminant analysis showing the percentage of fish eggs and larvae correctly classified according to their AA composition. Abbreviations as in Table 2

\begin{tabular}{|c|c|c|c|c|c|c|c|c|c|c|c|c|c|}
\hline \multirow{2}{*}{$\begin{array}{l}\text { Actual } \\
\text { group }\end{array}$} & \multicolumn{13}{|c|}{ Predicted groups } \\
\hline & $S p$ At & $S p \mathrm{~W}$ & $S p \mathrm{E}$ & Ss W & Ss E & $S p$ At & $S p \mathrm{~W}$ & $S p \mathrm{E}$ & Ss W & Ss E & $T t \mathrm{~W}$ & $T t \mathrm{E}$ & $M p \mathrm{~W}$ \\
\hline Sp At & 96.7 & 0 & 3.3 & 0 & 0 & 100 & 0 & 0 & 0 & 0 & 0 & 0 & 0 \\
\hline$S p \mathrm{~W}$ & 0 & 100 & 0 & 0 & 0 & 0 & 76.3 & 3.9 & 3.9 & 0 & 15.8 & 0 & 0 \\
\hline$S p \mathrm{E}$ & 0 & 12.5 & 87.5 & 0 & 0 & 1.7 & 13.6 & 72.9 & 3.4 & 5.1 & 3.4 & 0 & 0 \\
\hline Ss W & 0 & 0 & 0 & 100 & 0 & 0 & 0 & 0 & 89.7 & 5.7 & 3.4 & 0 & 1.1 \\
\hline Ss E & 0 & 0 & 0 & 9.7 & 90.3 & 0 & 0 & 0 & 11.1 & 88.9 & 0 & 0 & 0 \\
\hline$T t \mathrm{~W}$ & & & & 0 & 14.3 & 14.3 & 0 & 0 & 57.1 & 0 & 14.3 & & \\
\hline$T t \mathrm{E}$ & & & & 0 & 0 & 0 & 0 & 0 & 0 & 100 & 0 & & \\
\hline$M p \mathrm{~W}$ & & & & 0 & 2.9 & 0 & 8.8 & 0 & 5.9 & 0 & 82.4 & & \\
\hline
\end{tabular}


Table 4. Factor loadings for the 2 principal components of a discriminant analysis performed on AA (see Table 2 for amino acid abbreviations) of eggs and larvae

\begin{tabular}{|c|c|c|c|c|}
\hline & \multicolumn{2}{|c|}{$\begin{array}{l}\text { Eggs } \\
\text { Function I Function II }\end{array}$} & \multicolumn{2}{|c|}{$\begin{array}{l}\text { Larvae } \\
\text { Function I Function II }\end{array}$} \\
\hline Asp & 0.053 & -0.165 & 0.108 & -0.110 \\
\hline Ser & -0.002 & -0.105 & -0.089 & 0.144 \\
\hline Glu & -0.064 & -0.163 & 0.490 & -0.270 \\
\hline Gly & 0.005 & -0.075 & 0.023 & 0.178 \\
\hline His & -0.263 & 0.267 & -0.252 & 0.415 \\
\hline Arg & -0.054 & -0.197 & -0.239 & -0.117 \\
\hline Thr & 0.303 & -0.373 & -0.254 & 0.214 \\
\hline Ala & -0.124 & 0.020 & 0.234 & -0.012 \\
\hline Pro & -0.038 & -0.150 & 0.111 & 0.024 \\
\hline Tyr & 0.052 & 0.624 & -0.624 & -0.075 \\
\hline Val & 0.233 & 0.284 & 0.154 & 0.017 \\
\hline Lys & -0.069 & 0.207 & 0.405 & -0.086 \\
\hline Ile & 0.083 & -0.235 & 0.194 & 0.100 \\
\hline Leu & 0.119 & 0.223 & 0.150 & -0.075 \\
\hline Phe & -0.235 & 0.141 & -0.356 & 0.099 \\
\hline
\end{tabular}

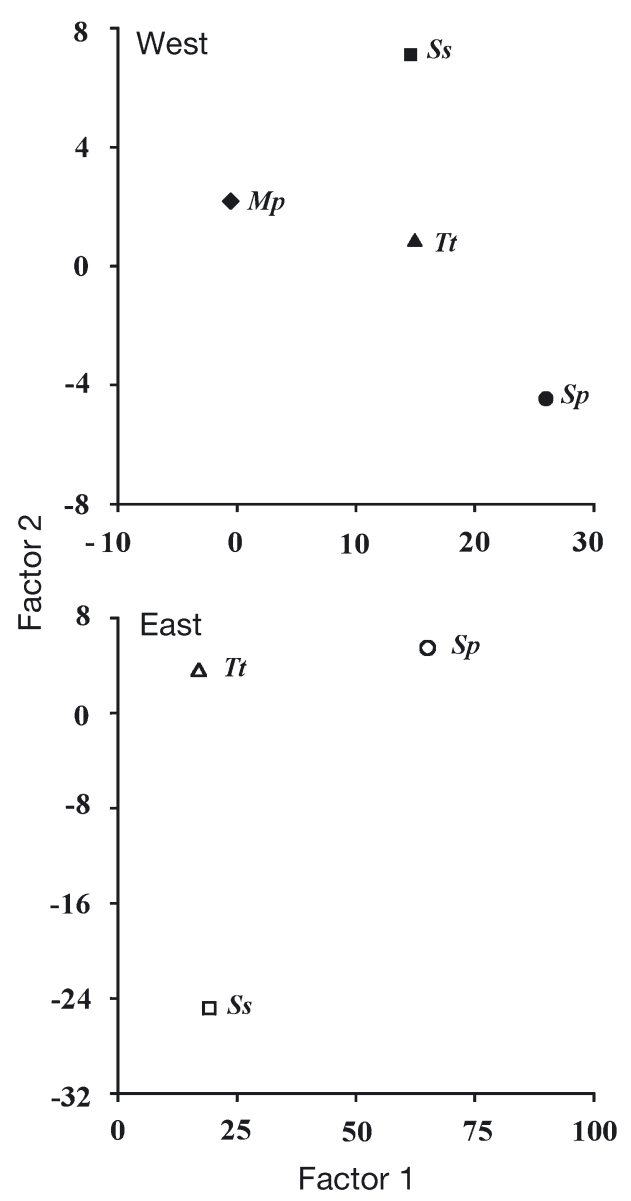

Fig. 3. Plot of the first 2 factorial analysis scores on larval abundance of fish species in the west and east of the Cantabrian Sea. West Cantabrian Sea (W: black symbols), East Cantabrian Sea (E: open symbols). Sardina pilchardus (circle), Scomber scombrus (square), Trachurus trachurus (triangle) and Micromesistius poutasou (diamond)

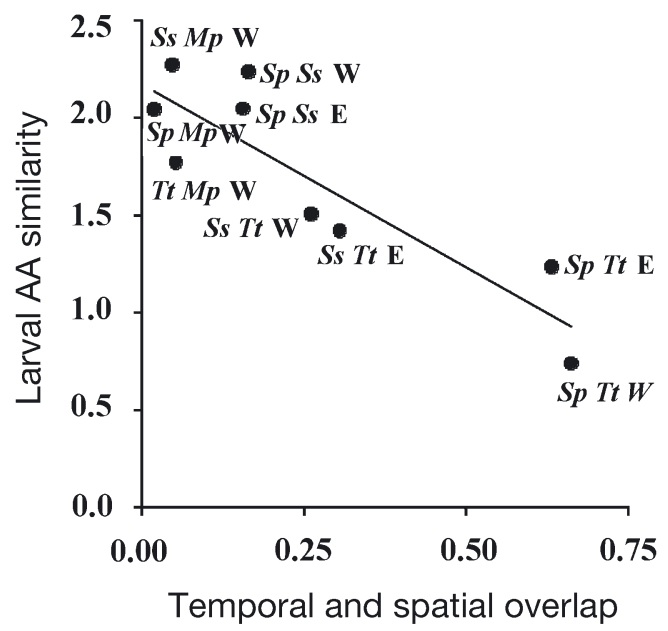

Fig. 4. Relationship between larval temporal-spatial overlap (Morisita index) and larval AA similarity (Euclidean distance) among fish species. Slope different from $0\left(r^{2}=0.78, p<0.005\right)$

\section{DISCUSSION}

Most of the variation in AA observed in the eggs was among different fish species, although significant variation was also observed among different areas within each species. The variation of the egg AA among areas could be due to either the age structure of the adult females or to changes in the oceanographic conditions/adult diet.

García et al. (1991) found spawning intensity variation between Galician (Atlantic coast of Spain) and Cantabrian sardines. These differences were explained due to the distinct age structure of the females in the Atlantic and the Cantabrian coast (Porteiro et al. 1986), with the youngest females in Portugal and the south area of Galicia, and the oldest ones in the east Cantabrian areas. Egg quality has been shown to be affected by both size and age of females (Buckley et al. 1991). Therefore, these changes in the amino acid profiles of eggs among areas could be due to differences in the age structure of the adults in the population.

With regard to the possible effect of oceanographic conditions on egg AA, egg biochemical composition of Sardina pilchardus, Scomber scombrus and Engraulis encrasicolus is known to vary according to prevailing buoyancy conditions (Guisande et al.1998). An increment of the larval lipid percentage and a reduction of the larval protein percentage was observed as water density decreases (Guisande et al. 1998); whereas when water density is higher, the percentage of protein is higher than the lipid in the larvae.

The AA of the eggs is also affected by the biochemical composition of the adult diet (Fiogbé \& Kestemont 1995, Pereira et al. 1998). Therefore, differences in the 


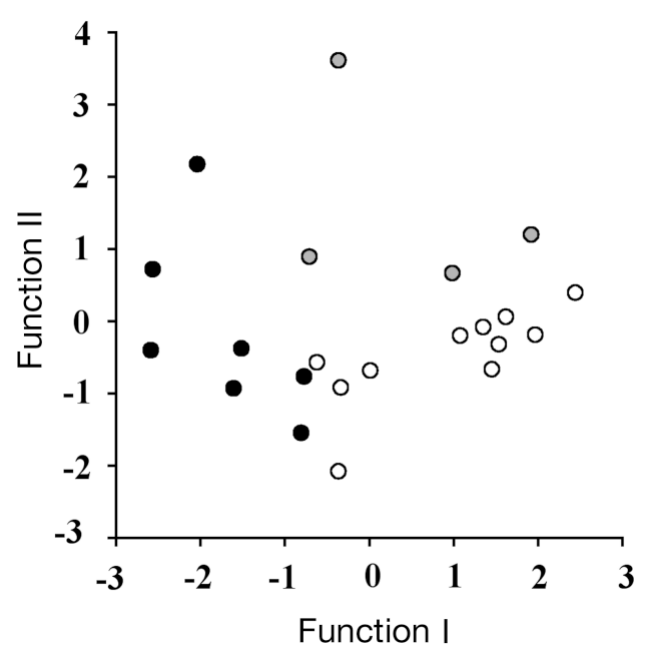

Fig. 5. Plot of the first 2 discriminant analysis scores for the biochemical composition of the seston size fraction 20 to 1000 $\mu \mathrm{m}$ (percentage of proteins, carbohydrates and lipids) in the Atlantic coast $(\cup)$, west Cantabrian Sea $(\bullet)$ and east Cantabrian Sea (O)

AA of the eggs among fish species and among areas within each species could also be partly due to differences in adult diet. This means that egg AA could also be used as an indicator of adult trophic competition among co-occurring fish species.

In contrast to egg AA, a higher variation was observed among areas than among species in the AA of the larvae. These variations could be due to differences in the biochemical composition of the food ingested by larvae in the different areas (Fig. 5). Larval sardine growth differs between the Atlantic and Cantabrian Sea, and these differences are associated with the quantity of food to be found among these areas (Alvárez \& Alemany 1992). However, MartinJézéquel et al. (1989) did not find a direct relationship between the free amino acids composition of seston size fractions and the midgut of Scomber scombrus and Trachurus trachurus larvae. Martin-Jéquézel et al. (1989) results can be explained either because clupeoids are selective feeders (Beyer 1980), and therefore they could feed selectively from all the food available in the seston size fractions, and/or due to the complexity and rapidity of all the processes involved during feeding, absorption, digestion and gut evacuation (Martin-Jézéquel et al. 1989).

Leibold (1995) mentioned that the trophic niche of a species should be divided into the 'requirement niche' and the 'impact niche'. Larval AA is a good indicator of the amino acids required by the larvae in their food (Ketola 1982, Conceição et al. 1998). Small changes in the AA of larvae could have important implications in terms of amino acids needed by the larvae. AA imbal- ances may increase amino acid loss and affect conversion efficiencies by increasing metabolic rates (see Conceição et al. 1998). This could be due to the fact that the lag time between food being ingested and being converted into larval biomass is probably too short to produce biomass with an optimal proportion of amino acids. Therefore, AA of the larvae is a good indicator of the 'requirement niche' for optimal growth. Moreover, if the selective feeding behaviour of larvae (on available food observed in clupeoids) (Beyer 1980) is due to the necessity of an AA balanced diet, larval AA would also be an indicator of the of the 'impact niche', and therefore, would serve as a good tool in the future study of food resources partitioning among larval fish species.

In addition to larval diet, oceanographic conditions can also affect larval AA. Conceição et al. (1998) showed that in the larval African catfish Clarias gariepinus, changes in the amino acid profiles at different temperatures, due to the synthesis of different proteins or a change in the proportions of various proteins synthesised during larval growth. Therefore, as well as the AA of the eggs, larval AA could also be used to discriminate among fish larvae populations of different areas (if there were differences in the oceanographic conditions between the areas). The hypothesis that larval AA is a good indicator of habitat conditions is corroborated by the higher similarity of larval AA when spatial and temporal overlap is higher (Fig. 4).

We concluded that the results obtained in this study clearly show that the AA of both eggs and larvae provides useful information about the ecology of pelagic fish species. Additionally, AA of both eggs and larvae is species specific, facilitating species identification. Moreover, the AA of both eggs and larvae varied among different areas and by species according to prevailing habitat conditions (probably temperature, salinity, and food quantity and quality), indicating that egg and larval AA can be used as a 'biochemical print' to trace niche resources used by each pelagic fish species.

Acknowledgements. This research was supported by the projects MAR99-0328-C03-01 and SEAMAR, and grants from Fundación Provigo to I.R. and from AECI (Agencia Española de Cooperatión Internacional) to A.R.V.

\section{LITERATURE CITED}

Abaunza P, Fariña AC, Carrera P (1995) Geographic variations in sexual maturity of the horse mackerel, Trachurus trachurus, in the Galician and Cantabrian shelf. Sci Mar 59:211-222

Alvárez F, Alemany F (1992) Regional growth differences in sardine (Sardina pilchardus Walb.) larvae from Cantabrian and Galician coast. ICES-CM 1992/H:9

Baynes SM, Howell BR (1996) The influence of egg size and 
incubation temperature on the condition of Solea solea (L.) larvae at hatching and first feeding. Aquaculture 199: 59-77

Beyer JE (1980) Feeding success of clupeoid fish larvae and stochastic thinking. Dana 1:65-91

Brown RW, Taylor WW (1992) Effects of egg composition and prey density on the larval and survival of lake whitefish (Coregonus clupeaformis Mitchill). J Fish Biol 40:381-394

Buckley LJ, Lough RG (1987) Recent growth, biochemical composition, and prey field of larval haddock (Melanogrammus aeglefinus) and Atlantic cod (Gadus morhua) on Georges Bank. Can J Fish Aquat Sci 44:14-25

Buckley LJ, Smigielski AS, Halavik TA, Caldarone EM, Burns BR, Laurence GC (1991) Winter flounder Pseudopleuronectes americanus reproductive success. II. Effects of spawning time and female size on size, composition and viability of eggs and larvae. Mar Ecol Prog Ser 74: 125-135

Conceição LEC, Ozório ROA, Suurd EA, Verreth JAJ (1998) Amino acid profiles and amino acid utilization in larval African catfish (Clarias gariepinus): effects of ontogeny and temperature. Fish Physiol Biochem 19:43-57

Conway DVP, Coombs SH, Fernández de Puelles ML, Tranter PRG (1994) Feeding of larval sardine Sardina pilchardus (Walbaum), off the north coast of Spain. Bol Inst Esp Oceanogr 10:165-175

Conway DVP, Coombs SH, Lindley JA, Llewellyn CA (1999) Diet of mackerel (Scomber scombrus) larvae at the shelfedge to the south-west of the British Isles and the incidence of piscivory and coprophagy. Vie Milieu 49: 213-220

Dubois M, Gilles KA, Hamilton JK, Smith F (1956) Colorimetric method for determination of sugars and related substances. Anal Chem 28:350-356

Fiogbé ED, Kestemont P (1995) An assessment of the protein and amino acid requirements in goldfish (Carassius auratus) larvae. J Appl Ichthyol 11:282-289

García A, Pérez N, Porteiro C, Carrera P (1991) Estimates of the sardine spawning stock biomass off the Galician and Cantabrian coast. ICES-CM 1991/H:35

Grahl-Nielsen O, Mjvaatten O (1992) Discrimination of striped bass stocks: a new method based on chemometry of the fatty acid profile in heart tissue. Trans Am Fish Soc 121:307-314

Guisande C, Riveiro I, Solá A, Valdés L (1998) Effect of biotic and abiotic factors in the biochemical composition of wild eggs and larvae of several fish species. Mar Ecol Prog Ser 163:53-61

Guisande C, Maneiro I, Riveiro I (1999) Homeostasis in the essential amino acid composition of the marine copepod Euterpina acutifrons. Limnol Oceanogr 44:691-696

Guisande C, Riveiro I, Maneiro I (2000) Comparisons among the amino acid composition of females, eggs and food to determine the relative importance of food quantity and quality to copepod reproduction. Mar Ecol Prog Ser 202: $135-142$

Guisande C, Maneiro I, Riveiro I, Barreiro A, Pazos Y (2002) Estimation of copepod trophic niche in the field using amino acids and marker pigments. Mar Ecol Prog Ser 239: $147-156$

Hillgruber N, Kloppmann M (1999) Distribution and feeding of blue whiting Micromesistius poutassou larvae in relation to different water masses in the Porcupine Bank area, west of Ireland. Mar Ecol Prog Ser 187:213-225
Horn HS (1966) Measurement of 'overlap' in comparative ecological studies. Am Nat 100:419-424

Ketola HG (1982) Amino acid nutrition of fishes: requirements and supplementation of diets. Comp Biochem Physiol 73: $17-24$

Leibold MA (1995) The niche concept revisited: mechanistic models and community context. Ecology 76:1371-1382

Lowry OH, Rosenbraugh NJ, Farr AL, Randall RJ (1951) Protein measurements with the Folin phenol reagent. J Biol Chem 193:256-275

Martin-Jézéquel V, Camus P, Poulet SA (1989) The partitioning of free amino acids between phytoplankton, zooplankton and ichthyoplankton in the Ushant region. Top Mar Biol 53:259-268

Maxwell MAK, Haas SM, Bieber LL, Tolbert NE (1978) A modification of the Lowry procedure to simplify protein determination in membrane and lipoprotein samples. Anal Biochem 87:206-210

Navarro JC, McEvoy LA, Amat F, Sargent JR (1995) Effects of diet on fatty acid composition of body zones in larvae of the sea bass Dicentrarchus labrax: a chemometric study. Mar Biol 125:177-183

Nissling A, Vallin L (1996) The ability of Baltic cod eggs to maintain neutral buoyancy and the opportunity for survival in fluctuating conditions in the Baltic Sea. J Fish Biol 48:217-227

Osse JWM, Van den Boogaart JGM, Van Snik GMJ, Van der Sluys L (1997) Priorities during early growth of fish larvae. Aquaculture 155:249-258

Pereira JOB, Reis-Henriques MA, Sánchez JL, Costa JM (1998) Effect of protein source on the reproductive performance of female rainbow trout, Oncorhynchus mykiss (Walbaum). Aquac Res 29:751-760

Porteiro C, Alvárez F, Pereiro JA (1986) Sardine (Sardina pilchardus, Walb.) stock differential distribution by age class in Divisions VIIIc and IXa. ICES-CM 1986/H:28

Rasoanarivo R, Folack J, Champalbert G, Becker B (1991) Relations entre les communautés phytoplanctoniques et l'alimentation des larves de Sardina pilchardus Walb. dans le golfe de Fos (Méditerranée occidentale): influence de la lumière sur l'activité alimentarie des larves. J Exp Mar Biol Ecol 151:83-92

Riveiro I, Guisande C, Lloves M, Maneiro I, Cabanas JM (2000) Importance of parental effects on larval survival in Sardina pilchardus. Mar Ecol Prog Ser 205:249-258

Silversand C, Norberg B, Haux C (1996) Fatty-acid composition of ovulated egg from wild and cultured turbot (Scophthalmus maximus) in relation to yolk and oil globule lipids. Mar Biol 125:269-278

Stergiou KI, Karpouzi ZS (2002) Feeding habits and trophic levels of Mediterranean fish. Rev Fish Biol Fish 11: $217-254$

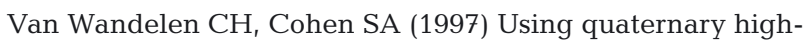
performance liquid chromatography eluent systems for separating 6-aminoquinolyl-N-hydroxysuccinimidyl carbamate-derivatized amino acid mixtures. J Chromatogr 763:11-22

Ulvund KA, Grahl-Nielsen O (1988) Fatty acid composition in eggs of Atlantic cod (Gadus morhua). Can J Fish Aquat Sci 45:898-901

Zöllner N, Kirsch K (1962) Über die quantitative Bestimmung von Lipoiden (Mikromethode) mittels der vielen natürlichen Lipoiden (allen bekannten Plasmalipoiden) gemeinsamen Sulfophosphovanillin. Z Gesamte Exp Med 135:545-561

Submitted: July 29, 2002; Accepted: June 24, 2003

Proofs received from author(s): September 9, 2003 